\title{
REHABILITATION OF URBAN HERITAGE IN THE SERVICE OF ETH- NO-NATIONAL DIVISIONS ON THE EXAMPLE OF SARAJEVO AND BANJA LUKA
}

Keywords:

cultural-historical heritage; ethno-national identity; rehabilitation; revitalization; space.

Author:

Dr. Ranka Perić-Romić is an Associate Professor at the Faculty of Political Sciences of the University of Banja Luka

Correspondence:

ranka.peric-romic@fpn.unibl.org

Field:

Special sociologies

DOI:

10.5937/politeia0-29337

Paper received on:

10.10.2020.

Paper accepted for publishing on:

03.12.2020.
Summary

This paper discusses the impact of the process of rehabilitation and revitalisation of the cultural and historical heritage of Banja Luka and Sarajevo on the strengthening of ethno-national policies/patterns of a divided society. Special attention will be paid to the processes of preserving the urban centres/historical cores of the mentioned cities, which are recognisable as places of separation and distancing for 'non-belonging' ethnic groups. In that sense, the rehabilitation of the urban heritage of Banja Luka and Sarajevo will not be exclusively problematised as preservation and aestheticisation of cultural and historical heritage 'per se', but as a kind of instrumentalisation of urban space for the purpose of overemphasising ethno-national identities in the post-war period. The survey will be primarily based on a comparative analysis of available data on the development of urban centres so far. The survey results indicate that the mentioned instrumentalisation of urban heritage is manifested through the planning and construction/renovation of specific facilities that (un)justifiably fit into the existing cultural and historical context characteristic of these cities. From that perspective, it is noticeable that the cultural and historical cores of Banja Luka and Sarajevo today have a far more significant role in promoting ethno-national identities and divisions than was the case in the past. The character of these processes does not have exclusively intentional features, but is conditioned by other current policies of urban development that do not have an ethno-national background. 
INTRODUCTION - THEORETICAL BASELINE

The raising of national awareness and national identity values in Bosnia and Herzegovina started in 1995, by the end of the war and the division of this former Yugoslav republic into two entities (the Federation of $\mathrm{BiH}$, the Republic of Srpska) and the Brčko District. The main urban centres of Sarajevo and Banja Luka represent spaces for the incorporation of national identities in their citizens' minds, combining them with the dominant forms of political ideology and ideology directed towards post-socialist, urban development. In both cities, through the protection of the existing cultural and historical heritage located in central urban spaces, the creators of the construction of physical and symbolic space develop ideological constructs of ethnic narrative which leads to the creation of specific mental structures of identification with the belonging nation. On the other hand, emphasising ethno-national values contributes to deepening the gap within an ethnically divided society. The basis of this hypothesis can be found at Lefebvre (Lefebvre, 1990), who pointed out that the city represents the state of social consciousness, i.e. it is a visual reflection of the social community and the state of society in which it is located and ultimately, it is the space of reproduction of capital. Later, in his first and second thesis for the renewal of urban sociology, referring to Lefebvre, Bassand said that the urban phenomenon can be considered as an imprint of the transformation of global societies in space (agrarian, industrial and information), and that the social phenomenon reveals social, economic and cultural processes (second thesis) (Bassand, 2001:345, 346). Although Bassand's theses are primarily based on modern (globalisation) urban trends, in a broader context, observing that modern war conflicts are incorporated into global processes of establishing geopolitical, military and economic domination, and that they are always accompanied by the interests of countries which are (were) directly or indirectly involved in the conflict, it is possible to apply them to the example of larger cities in Bosnia and Herzegovina, which, after the war, certainly use the principles of neoliberal development in a rather limited way. Bassand's eleventh thesis ..."Starting from that cultural heritage, urban types, their individual and collective protagonists by name build the identity that gives meaning to their action" (Bassand, 2001:351) provides a basis for descriptive analysis of the two cities that are the subject of this paper in the context of the significance of the rehabilitated cultural heritage, as well as the newly built facilities of a symbolic character that determine and define the state of consciousness and the directions of development of an urban society. Bassand also lists four key actors that influence the creation of urban space (experts - urban planners, architects, engineers; economic actors - owners of large capital of various types; political actors - political leaders, political parties and citizens - civil sector, NGOs, etc. In terms of a theoretical understanding of the topic, it is important to emphasise the role of political actors who, on the basis of the political discourse, lead, encourage national rhetoric, thus contributing to maintaining a culture of remembrance of past war events, thus ensuring their own stability on the political scene. Accordingly, in contrast to the socialist period, the influence of political actors was observed through centralised decision-making and a planned economy that was conceptually carried out and implemented in spatial development and urban planning. In the post-war period, 
these actors acquire other meanings. Decentralisation, deregulation of the state and the development of neoliberalism lead to the strengthening of the link between political and economic actors, so often public spatial development policies of cities are subordinate to private interests of capital owners, as evidenced by the usurpation of public spaces, as well as frequent changes in regulatory plans, and illegal construction. Also, political actors are important from the aspect of providing support to foreign investments by close and friendly countries. The internal development of cities under the domination of political actors in the case of both mentioned cities certainly takes into account the rehabilitation of urban heritage that encourages national identity values. Pajvančić-Cizelj and Maksimov state that in modern approaches to the protection of cultural heritage, the state and its professional bodies no longer hold a monopoly on the interpretation of heritage and the recognised social construction leads to its openness and democracy (Pajvančić-Cizelj and Maksimov, 2016:252) ${ }^{1}$. However, it should be borne in mind that in terms of freedom of construction of meaning on certain facilities of material culture, freedom of attributing or adding meaning through the imposed new value system can give them a completely distorted meaning contrary to the narrative and volarisation they have through historical context. Precisely the sociological analysis of the rehabilitation of the cultural and historical heritage, as well as the later construction

1 Pajvančić-Cizelj cites Pendlebery's (Pendlebery, 2008) view that ..."within the new phase that he calls the 'age of consensus', heritage is no longer seen as a static legacy in which immutable values are imprinted, but as a socially mediated and dynamic process" (Pajvančić-Cizelj, Maksimov 2016: 252) which is partially problematised in the analysis of this paper, not in a way to challenge, but to critically question the possible effects of (mis)use of cultural and historical heritage. of new identifying urban symbols, can be considered in the direction of the above.

\section{(RE)CONSTRUCTION OF URBAN IDENTITIES AND SYMBOLIC MEANING}

The difference between the implicit identity of the city and the ethno-national identity of the city lies in the experience of its physical, i.e. material characteristics and the way they present themselves to citizens and how citizens perceive them. In this particular case, they are closely connected with the culture of remembrance and the experience of certain urban artifacts that can change their meanings in different time periods. "The identity of a city can be defined as a set of unique features and characteristics that provide lasting recognition of one city compared to other cities, by which it differs from them and is recognised as special" (Spasić, Backović, 2017:16). Urban space as an abstraction is concretised through a place as a locality, not only of the material, but also of the symbolic plane within which a kind of identity is acquired. Therefore, urban space itself will not produce identity values if it does not contain places within which the use of symbols encourages national awareness and collective consciousness. The identity of a city has two sides, internal and external. The first represents the experience of the urban residents themselves, while the second side is the image or perception from the outside - how the city is seen in the eyes of others. Both of these sides are interconnected. (Spasić, Backović, 2017:16-17). It should be emphasized that the existing power structures are always in charge of the sustainability of collective consciousness and memory, as well as for possible suppression and deliberate forgetting of certain historical events. For example, in the former Yugoslavia, after the 
end of World War II, many memorials were built to strengthen the ideology of Brotherhood and Unity, which aimed to establish peace and build a new communist society among nations that contributed to the establishment of freedom, despite the drastic difference in the number of victims, memorial monuments to victims of fascist terror ${ }^{2}$, also social standard facilities were built (Youth Homes, JNA Homes, Sokol Homes, etc.) which created a new form of post-war identity reflected in the Yugoslav nation.

If we consider urban space as an arena within which national identity values (Radović, 2013), collective perceptions and memories can be encouraged, it is important to note that places containing material and physical remnants of earlier events important for the development of ethno-national consciousness have a more dominant role in individual and collective consciousness of the belonging nation than those spaces in which that connotation is not recognised. Exactly these are the places by which cities differ and stand out. Creating a culture of remembrance, and even encouraging the construction of ethno-national identities can be considered as a political instrumentalisation of the past, which is justified in the public discourse of the political elite if there are instruments and mechanisms of deliberate repression and denial in earlier periods. "The content of the leading ideologies that are publicly promoted in a society mainly depends on the top of the social and political pyramid, and how it is implemented also depends on the lower-positioned actors" (Radović, 2013:34). Radović believes that all those who contribute to the creation of the city as a text ${ }^{3}$, and who imple-

2 The use of the term Ustasha terror in everyday speech was almost forbidden, under the excuse of insulting the feelings of the Croatian people.

3 The space in which the contents of symbolic identity character are read, seen, offered and promoted. ment identity policy with various means, can be called entrepreneurs of identity.

Starting from the fact that identities (even ethno-identities) is a kind of process that arises within the discourse, socio-historical context, and which is created and understood as a product of specific strategies of expression... (Hol, 2001:219), revitalisation of existing urban heritage for the purpose of strengthening national awareness, repurposing or renaming can serve as powerful means in national homogenisation and highlighting diversity. Thus, the urban rehabilitation of historical heritage can contribute to the strengthening of political structures to the extent that it creates a growing sense of belonging and uniqueness. Generally speaking, ethno-national rhetoric contributes to the preservation of the political positions of power of post-war society, encouraging memories of previous war events. ${ }^{4}$ The use of the terms urban regeneration or urban rehabilitation refers mainly to changes in the city that can be structural, substantial, functional or some other nature and occur as a result of development changes. The goal is to restore liveliness to certain spaces (or to give them a new meaning - Perić Romić). Regeneration means the

4 In addition to the two cities that are the subject of this paper, an example of a city that affects the strengthening of ethno-national identity through rehabilitation and reconstruction of cultural and historical heritage affects is the city of Mostar, which is still considered a territorially divided city between Bosniaks and Croats. The city symbol is the Old Bridge built around 1567 by Süleyman the Magnificent. During the war in the 1990s, the bridge was damaged and then demolished by the Croatian Defense Council on November $9^{\text {th }}, 1993$. Its restoration and reconstruction (completed in 2004) had an exceptional ethno-national identity value among the Bosniak people. Traditional craft shops in its immediate vicinity have been rehabilitated as a type of oriental culture that has been preserved by Muslims from the period of Turkish domination in Bosnia and Herzegovina. After the reconstruction of the bridge, the city remained a territorially divided city between the two peoples. 
restoration of damaged urban tissue, while revitalisation means returning activities to abandoned parts of the city by raising the quality of life. In a certain sense, the term urban reconstruction is especially important for the topic of the paper, and it means the reconstruction or rebuilding of damaged facilities (Čaldarović, 2010:70-72).

Lefebvre's attitude that the city is a projection of society in space, and that by creating a city people shape themselves too, confirms the attitude that social relations produce space to the extent that space itself shapes society. Therefore, the contextual study of urban space from the scientific aspect is especially justified, and especially important for those societies that emerged from the war and thus started their way on the path of independent development. Speaking the language of the Chicago urban school, the city is also a state of the human spirit determined by the context of time and socio-economic and political circumstances. Social relations and processes in the city are based on the symbolic level of experience of space, as well as its objects. The political power to present certain urban physical structures in accordance with the current ruling ideology and contextual framework will affect the social shaping of public space, which may be significantly different than in an earlier period. For example, in the pre-war period, the city centre of Sarajevo (Baščaršija) was a symbol of the rich historical heritage of Bosnian-Herzegovinian society, mainly from the period of the Ottoman Empire for most of the inhabitants of Bosnia and Herzegovina. ${ }^{5}$ Saraje-

5 The period of Baščaršija's origin dates back to the 15th century and the founding of the city of Sarajevo by Isa-Beg Isaković. Among the most important buildings in the centre of Sarajevo and the Old Town are: Gazi Husrev-Beg Mosque, Sahat Kula [Clock Tower], Sebilj, Gazi Husrev-Beg Bezisan, Cathedral, Ashkenazi Synagogue, Sarajevo Cathedral, Old Orthodox Church, Emperor's Mosque, Isa-Beg's vo was considered a multiethnic city, so the population structure did not allow different representation of this urban space. This is supported by the fact of the pre-war existence of Obilićeva Street, which stretched from Baščaršija to Grlića brda (Radović, 2013:209). However, after the end of the war in Bosnia and Herzegovina in 1995, Baščaršija became an ideological construct for the development and consolidation of Bosniak national identity encouraged by the Islamic religion, which revived abruptly after the war and the communist period. This is supported by the fact that the largest number of street names in this part of the city referred to the return of earlier street names, that were not associated with significant names of the Bosniak people, but with the period of the Ottoman Empire. In this way, the experience of physical urban structures projected the experience of the centuries-old tradition of the existence of Muslims (Bosniaks) in the mentioned area $^{6}$. Thus, the experience of (symbolic) urban space depends on the way in which it is presented and in which it is experienced through social participation. Specifically, in Sarajevo, a distinction can be made between a heritage that is older and rehabilitated, and a new heritage that is "hybrid", whose symbolic value contains more recent narratives from the period of the war, and whose symbolic value is completely different (Kassouha, 2019). The creation of projected identities strengthens individual identities within the same community, i.e., ethnical group, by promoting a common destiny and past that is linked to their ethnic or national background. The social aspects of projected identities produce a silent dialogue which is the result of messages of symbolic artifacts understandable to

Hamam, City Hall, etc.

6 Muslims as a people or ethnic group were officially recognized in the SFRY in 1971. 
members of a particular ethno-national structure and which reaches out to individuals through the visual and symbolic messages it carries within itself. The historical heritage gains the special kind of volarisation in the touristic part of the city, while with the construction of new urban contents of symbolic value or protection of special material structures related to certain events, it mainly works towards creating symbolic thought structures in order to protect from oblivion. In that sense, Kuljić points out that the conflicting parties are always inclined to emphasize their suffering without understanding the crimes committed against other peoples, thus contributing to the strengthening of group or national identities. However, it should be insisted on maintaining the discourse that crimes have been committed on all sides, because only this knowledge contributes to the development of critical awareness and represents a constructive process on the way to strengthening national identity. Maintaining memories saves past events from oblivion, but also contributes to the possible modification of the past in accordance with one's own needs. Evoking the memory of certain events that are painful for one nation, on the other hand, affects various forms of forgetting and suppressing crimes committed against others. (Kuljić, 2006). The demystification of oblivion and selective memory significantly contributes to the creation of national identity and the decline of nationalism. Therefore, the culture of remembrance can be specifically legitimised through the protection of material facilities within the urban space. In the cities that survived the war, there are preserved artifacts that remind us of previous events and which are not preserved as a priority for tourist promotion as much as to preserve awareness of past survived and endured times. Only a secondary volarisa- tion is directed in the tourist offer with the aim of gaining compassion and understanding for the war events to which the city was exposed. Even this approach in understanding the management of cultural heritage or new urban buildings and facilities that aspire to become a permanent identity of the city is managed through various mechanisms of political action whereby politics can be directly or indirectly involved. Creating an image or vision of the past complies with today's needs (Kuljić, 2006). In particular, the ruling political structures use all available mechanisms for the purpose of their own sustainability, and in that sense, through the symbolism of individual facilities of content or facilities of urban space and supporting the culture of remembrance, the narrative of past events is encouraged. Political subjects use such consciousness of the society to present themselves as a saving factor or element that protects the community from similar events. "At the same time, the problem of creating symbolic identity structures concerns the relationship of power, especially between the world of life of ordinary people and the mass media, as well as other agents of popular cultural and political production of meaning..." (Spasić, Backović, 2017:17).

Hence, urban identity influences the peculiarity of the urban way of life through the form not only of inherited identity (cultural and historical heritage of the city itself), but also through projected identities as new forms of future heritage with which residents identify through lived experience. This layering of urban identity is based on the difference between what is found and what is acquired, i.e., on the difference between what identifies the city and who identifies with the city. The new, projected urban identities have a far stronger symbolic than material value, in contrast to the inherited cultural heritage, 
and are mainly in service of strengthening the ethno-national structures in the cities that went through the war events.

\section{CHALLENGES OF TRANSITION AND POST-WAR PROCESSES IN SARAJEVO}

After 2000, Sarajevo significantly changes its appearance under the influence of various investment funds mainly intended for the reconstruction of destroyed city infrastructure, reconstruction of roads, hospitals, schools, housing and the like. Islamic countries had a special influence in the construction and rehabilitation of Sarajevo. BBI (Bosnia Bank International) with stakeholders (The Islamic Development Bank, Abu Dhabi Islamic Bank and Dubai Islamic Bank) initiates the construction of a BBI shopping centre on the site of the destroyed Sarajka (Gül, Omićević, 2013:684), thus starting the process of investing in a new pro-Western look of the city, but with the investment of money from eastern Islamic countries, and it gives a kind of new symbolic and aesthetic spirit. Therefore, the urban renewal of the city of Sarajevo is accompanied not only by the sanitation and rehabilitation of destroyed facilities, but also by modern (imposed) global architectural patterns of city development that violate the existing identity (Husukić, Zejnilović, 2017: 98). It should also be noted here that the specificity of the urban appearance of Sarajevo originates from the intersection of the influence of the Ottoman and Austro-Hungarian empires, and later of the socialist, Yugoslav development. Unclear directions of urban development, as well as post-war, economic, social, and even national trauma, will create confusion in many segments, on the one hand, the need to preserve the traditional values of the city, and on the other hand, the desire to follow Sarajevo's example of European cities. Other European cities which did not survive the war, but went through a period of post-socialist transition, such as Prague, Sofia, Zagreb, Ljubljana and others, also needed to develop urban development and revitalisation in the direction of European standards and neoliberal cities. Along the way, they faced several problems such as: unplanned urbanism, incomplete urban planning, imbalance of public and private space, excessive construction, revitalisation and market-driven construction, neglect of the profession in relation to other actors in space creation, etc. (Zlatar - Gamberožić, Svirčić - Gotovac, 2019).

The post-socialist transformation that took place during the war and post-war events will cause, as in other cities, an increase in foreign capital in the form of construction of many facilities, mainly trade activities, which visually create a sense of recovery of the society, but significantly change the earlier appearance of Sarajevo. The restructuring of the city began on neoliberal principles. The need for the society to be market-oriented and to enable the input of foreign capital will affect the construction of facilities mainly for commercial purposes, which will significantly change the appearance of the city of Sarajevo. Office and commercial spaces reach three quarters of new post-war projects, which especially develops the tertiary economy and new ways of expenditure (Martín-Díaz, 2014:312). As some Islamic countries were interested in the rehabilitation and preservation of the traditional cultural core in Sarajevo, among which Turkey was in the forefront, other forms of investment in urban construction came from the Islamic part of the world, thus strengthening the ethno-national identity based on the Islamic religion. It is especially important to point out the investors from Malaysia and Saudi Arabia who have built large constructi- 
on projects such as BCC (Bosmal City Center) or Sarajevo City Center (Diaz, 2014:312). Such and other urban projects that are mainly built in the urban central zones of the city lead to significant diversification of urban space and functional diversity that does not follow equally strategic directions of city development $^{7}$ and leads to functional confusion which is characteristic of other postsocialist cities such as Sofia, Prague, Warsaw, etc. (Hirt, 2006; Sykora, 2007; Stanilov:2007). Čaldarović points out that the increased concentration of business facilities reduces the possibility of a modern tendency to unburden the city centre because there is excessive urbanisation, which implies an increase in traffic density and population, accumulation of accompanying facilities, etc. (Čaldarović, 2011:48-49).

The appearance of illegal construction, as well as the dominant influence of political and economic factors in the creation of urban space, will contribute from the professional aspect to the illogical and ambiently inconsistent construction of many facilities. "Contemporary architecture in Sarajevo defies time and consciously creates urban turmoil, thus distorting the once unique urban identity of the famous architectural tradition" (Husukić, Zejnilović, 2017:98). Illegal construction certainly contributes to this situation as an expression of the domination of big capital and the new quasi-elite in a society characterised by corruption and crime, in which private interest takes precedence over the general interest and the public good (Petovar, 2003; Petovar, Vujošević, 2008). Residents are changing the value system in a new concept of the development of an illiberal society in which consumer culture is becoming the backbone of social

7 Development Strategy of the City of Sarajevo 20122020 . orientations. The specificity of understanding Sarajevo stems from the complex inherited and newly projected social relations. The inherited patterns refer to the multiethnicity of the city, which used the national structure of the inhabitants, as well as the cultural diversity, to nurture a special narrative and a special lifestyle of Sarajevo's citizens adapted to that context. Therefore, the places marked by the artifacts of the Ottoman Empire were not interpreted as places of spreading Islam but as a space of common culture of all those living in Sarajevo. The projected postwar relations are dominated by the need to emphasise diversity, where each urban space is used as a possible place to confirm national identity. Thus, under the pressure of different times, one and the same space is interpreted in two completely different ways. On the other hand, the reconstruction of the city, as well as the construction of facilities in which consumption dominates, creates new lifestyles of the inhabitants, based on consumer habits, contributing to the emphasis on class and status strata of the society opposed to the former dominant working class. Thus, the construction of a large number of shopping centres creates an apparent picture of the city's development which does not correspond to the real situation of its inhabitants, but contributes to investment development which is the least profitable for citizens in the long run because it contributes the least to development and investment in production capacities, and that is the backbone of the society. The appearance of shopping centres stifles small shops, but they are still preserved in the traditional core of the city, because due to the attractiveness, the constant fluctuation of the local population as well as tourists is maintained. However, citizens are changing their life habits and lifestyles towards the creation of a consumer society in which 
consumption is linked to entertainment and new areas of social communication (Hromadžić, 2008). Thus, for example, shopping centres represent non-places (Auge, 2001) that essentially distance citizens from traditional urban values and cultural heritage by depicting a space that has no deeper, symbolic or value meaning apart from encouraging consumption.

Cities affected by the war usually applied rapid interventions in space for several reasons: to normalise life as soon as possible, first of all to provide housing and functioning of all services of the system, and to compensate for economic, social and any other loss. In that sense, political actors are important for providing conditions for the action of economic actors (foreign investors) and systematic urban planning subordinated to market mechanisms. 'In many cases, pure financial participation in shaping the post-war identity of the city has resulted in aesthetic sterility' (Husukić, Zejnilović, 2017:103). The identity of the city of Sarajevo was damaged not only through the war. Preserved artifacts from that period (plaques on the facades that speak of the suffering of civilians, as well as red roses) had the function of attractiveness, which was based on the ugliness and empathy for the surviving past. Therefore, a completely new phenomenon and the opposite urban process of the hitherto known concepts of revitalisation and reconstruction is emerging in Sarajevo. Such a new phenomenon could be called counter-revitalisation and rehabilitation of urban space because it means effort and even investment in the preservation of vulnerable areas or those that remind us of the events of the war. These processes can include the construction of numerous monuments to war victims, as well as a memorial centre that took place much faster than the renovation of the theatre, museum and Olympic complex (Dra- žeta:2018:63). It is important to mention that revitalisation also means preserving ruined and older buildings within the city, not just building new ones. According to importance, counter-revitalisation and rehabilitation belongs to the new urban elements on which it is possible to develop the strategic development of the city in one segment ${ }^{8}$.

Certainly, after the war, the legislation regarding the development of the city and strategic planning did not give the expected results, due to the slowness in decision-making, as well as the slowness in resolving property disputes. There is an obvious increase in spatial manipulation, which is the most evident in the rapid changes of planning documents, as well as the subsequent legalisation of constructed facilities. Urban space becomes a space of consumption, a commodity that can be cashed in without a clear vision of preserving the urban identity that was once based on multiethnicity. It can be seen from the above that the lack of multiethnicity is not the main cause of the loss of Sarajevo's special identity.

\section{IDEOLOGICAL CONTEXT OF REVITALISATION OF THE URBAN CENTRE OF SARAJEVO}

The revitalisation of the urban centre of Sarajevo, which truly consists of a traditional core with elements of Ottoman culture that left deep traces on the urban identity of the inhabitants, is disrupted by surrounding construction and interpolations in an area where urban stratification is neglected and which creates confusion in visual perception and mental and identity experience. Although the very centre of Sarajevo is protected

8 Applying for funds for reconstruction and development, for the protection of cultural and historical heritage, then for the development of tourism, etc. 
by legal acts as a cultural heritage, this does not necessarily mean that it is truly preserved if it failed to preserve the aesthetic experience and valorisation of material heritage under the pressure of newly built physical structures. However, the rehabilitation of urban heritage in Sarajevo's city centre was mainly related to the preservation of inherited cultural heritage through the process of protection of existing physical and material facilities ${ }^{9}$, which is regulated by certain legal acts, while in this area more attention was paid to building a new Islamic identity in order to enhance the ethno-national structure that may affect the division in relation to other national groups. In the context of the above-mentioned, it is testified by the construction of the Centre for the Qur'an and Sunnah by the Faculty of Islamic Sciences, which will be positioned in Telali Street between the City Hall and Baščaršija (Karaca, $2018)^{10}$.The mentioned centre aims to popularise the study of the Qur'an and Sunnah. On the other hand, although construction is prohibited in this area, in the immediate vicinity of the Serbian Orthodox Church dedicated

9 During June 2020, the City of Sarajevo received approval for a loan in the amount of BAM 10 million, which was used for financing the reconstruction and rehabilitation of the City Hall Museum, the Bistrik railway station building, as well as the reconstruction of the Eternal Flame building. The town hall was built in 1896 and after World War II, it became the National Library. The City Hall was significantly destroyed during the war in August 1992 and the library collection was burned. The renovation of the City Hall began in 1996 and lasted until 2014, and the reconstruction was performed according to the original documentation. Today, it is used for ceremonial occasions, exhibitions and other cultural events, as well as for City Council sessions (City Hall, Sarajevo, n. d).

10 On the occasion of the construction of the mentioned centre, Hafiz Abdulaziz Drkić stated that the goal of this kind of institution is to popularise the study of the Qur'an and Sunnah in Bosnia and Herzegovina, and to strengthen the religious identity of Bosniaks through various educational activities. to the holy archangels Michael and Gabriel in Baščaršija, threatens the construction of a building that would mostly cover the church and endanger the ambient protected area ${ }^{11}$. The Islamisation of Sarajevo and the building of a new national identity in which the Islamic religion plays a dominant role can be seen through the significant investments of Turkey in the city at the end of the 1995 war. Namely, Turkey participated in the reconstruction of the Emperor's Mosque, Isa-Bey's Hammam, and other traditional buildings located in the traditional core of the city. Turkey's interest in rehabilitating the historical urban heritage of Sarajevo, apart from strengthening Islam in this area, can be observed from the aspect of strengthening ties with the former territories of the Ottoman Empire (Badescu, 2016:6), by which even today it tries to impose itself as the dominant force, creating a certain postcolonial relationship ${ }^{12}$.

The urban renewal of Baščaršija, which took its authentic form during the 15th century, is the subject of many disputes, which are mainly between university professors and

11 Thanks to the Commission to Preserve National Monuments of Bosnia and Herzegovina, which sent letters to several addresses, such as the Federal Administration for Inspection Affairs, the Federal Ministry of Spatial Planning, Municipality of Stari Grad, and the Institute for the Protection of Cultural and Historical Heritage of Sarajevo Canton (Bascarsija is being built: 'some' building is being built near the old church complex, n. d).

12 In the wider area of the city of Sarajevo, a large number of mosques were built, whose construction was financed by Islamic countries that in the earlier historical period had no ties with Bosnia and Herzegovina. Saudi Arabia built the King Fahd Mosque, Indonesia the Istiklal Mosque. Although the construction of mosques was partly justified by the need of citizens to practice their religion (whose role was significantly reduced in the socialist period), the fact is that newly built religious buildings with other cultural institutions (e.g. library, cultural centre, etc.) do not fit the architectural tradition of Sarajevo, nor does the Islam, propagated through the mentioned facilities correspond to the traditional practice of Islam in Bosnia and Herzegovina (Badescu, 2016:6). 
the Committee for Monuments and Cultural Sites and are a reflection of insufficient involvement of the profession, which is the case in other areas, too. New pavements of flat geometric shapes are replaced by the irregular structures of stacked stone, the so-called cobblestones, which significantly influenced the destruction of authenticity, which began much earlier. The reconstruction and revitalisation seem to have succumbed to the challenges of adapting the most visited urban place to the comfort needs of its use. This will certainly result in changing the appearance of certain facilities in Baščaršija itself in the traditional trade and craft core in order to adapt the mentioned space to its users, primarily walkers.

\section{RECONSTRUCTION AND REVITALISATION OF THE URBAN HERITAGE OF BANJA LUKA - WITH OR WITHOUT A NATIONAL SIGN}

Unlike Sarajevo, Banja Luka did not suffer the war during the 1990s. This certainly affected the special way of its post-socialist development, when certain elements of urban rehabilitation and revitalisation were and are more encouraged by the preservation of cultural and historical heritage than by the encouragement of ethno-national divisions. The development of Banja Luka is related to the period from the 15 th century when the name of the city was first mentioned in the documents of King Vladislav II of Hungary, and it achieved significant development during the reign of Sofi Mehmed-pasha and Ferhad-pasha Sokolović, when it became the seat of the Bosnian pashaluq (15531639) (Džaja, 1962; Ševo, 1996; Mikić, 1995). Intensive development of Banja Luka took place in the Austro-Hungarian period, when many important facilities were built, such as a grammar school, hospital, land bank, railway station, military command and many others, among which facilities in Gospodska Street especially dominated. Representative buildings, which were preserved despite the devastating earthquake in 1969, were built during the reign of Ban [Governor] Svetislav Milosavljević Tisa, when Banja Luka became the seat of the Vrbas Banovina in 1929. Among them, the "Banski dvor" and the "Banska uprava" stand out, as well as the Serbian Orhodox Cathedral, which was built between them and destroyed during World War II.

Understanding the urban rehabilitation of the city of Banja Luka, the construction of the Church of Christ the Saviour can be observed as a facility whose construction encourages ethno-national divisions. However, it should be borne in mind that a Holy Trinity Church was built on the existing site in the period between the two world wars, which was significantly damaged during the bombing by the Germans in 1941, and later completely demolished. In that context, the construction of the mentioned church represents the return of identity values to the city, and the strengthening of aestheticisation in the built urban space more than the strengthening of ethno-national divisions, but it certainly represents the incorporation of the symbolic meaning of the place as a living space of Serbian people. Rehabilitation of urban heritage in this case can be considered the restoration and preservation of cultural and historical heritage "per se". In addition to the construction of this church, during 1993 the Ferhad Pasha Mosque was rebuilt, which was originally built in 1579 and demolished in 1993. In 1950 it was included in the cultural heritage of Bosnia and Herzegovina and on the UNESCO World Heritage List. Its renovation lasted several years (it started in 2007) and was officially opened in 2016 . The renovation 
of this important religious facility, which certainly belongs to the identity values of Banja Luka, was financed with money from the citizens, the Turkish State Agency for International Cooperation and Development and the Government of the Republic of Srpska (Maksimović, 2015). The adoption of certain strategic documents, including the Strategy for the Development of Culture of the City of Banja Luka until 2028, includes the rehabilitation and reconstruction of certain facilities in the city that will aesthetically and culturally affect the specific look of modern Banja Luka, which preserves its historical heritage. An example is the reconstruction of the old Milanović house, located in Ban Milosavljević Street, which will be promoted to the "Banja Luka House of Books". Intensive renovation and rehabilitation in Banja Luka is being performed in the city centre itself, with Gospodska Street in its very centre. The change in the ownership structure and privatisation of buildings caused by the new social system, as well as the revitalisation and reconstruction of certain facilities did not change the functionality of Gospodska Street, which is dominated by catering and trade activities, as is the case with Baščaršija.

With the adoption of the revision of the part of the regulation plan of the central area of Banja Luka in 2018, it continued to contextually nurture and develop the urban heritage from the period of the beginning of the 20th century. The novelty that the existing regulatory plan advocates, refers to the change of the vertical line from the old bus station, the Museum of Contemporary Art to the Church of Christ the Saviour and the monument to Ban Milosavljević, and then to the space that was originally intended for the construction of a shopping centre and now a monument to fallen soldiers of the Republic of Srpska (Perić Romić, 2018:99). Conceptual solutions in terms of relieving traffic in this part of the city and the protection of historical heritage have yet to show their effects depending on the degree and dynamics of construction and action according to the mentioned plan. The construction of a memorial to fallen fighters in the very centre of the city represents the strengthening and consolidation of the national consciousness of the Serbian people in Banja Luka, which, although not the capital of the Republic of Srpska according to the Constitution, is an administrative, political, cultural and educational seat. The construction of a monument to fallen fighters would contribute to strengthening the culture of remembrance of all those victims who perished in order to preserve the Serbian people in this area. Unlike Sarajevo, Banja Luka has no protected artifacts reminiscent of past war events, inciting interethnic intolerance through empathy for the events of the last war. What is common for both cities is the change of street names that glorify the historical figures of the people belonging to them. One of the most important streets in Banja Luka, which was originally called "Carski Drum" [Imperial Road], was renamed to King Petar I Karađorđević Street and Mladen Stojanović Street, as were many others. Interpolations into already built urban structures, as well as insufficiently professionally controlled housing construction in the inner city, threaten to disrupt the visual perception and mental experience of the traditional core of Banja Luka, which is one of the consequences of post-socialist transformation.

In terms of preserving the cultural and historical identity of Banja Luka, it is important to mention the long-term reconstruction of the Kastel Fortress, which is taking place in phases ${ }^{13}$. The reconstruction of the Petar

13 The reconstruction is financed partly via the European Union and from the budget of the City of 
Kočić Park was criticised for its modern appearance, and misunderstood by many Banja Luka residents. The set music pavilion replaced the former old fountain, which was considered by many to be a symbol of Banja Luka ${ }^{14}$ (Perić Romić, 2018:97). “The architect's goal was to create a new space that achieves the meaning of existence, provides users with an experienced space, emotion, a pleasant state of mind, a pleasant atmosphere, a true artistic and life spectacle - to create an architecture open to any experience, aware that success judges time" (Stanković and Stanković, 2010: 182). Čaldarović (2011) warns that the reconstruction of public spaces can often lose its important determinant, and that is "availability to all", which the people of Banja Luka seem to have experienced in that way by building the cafe bar Staklenac in the reconstructed park.

Although both cities strive to preserve and rehabilitate the cultural and historical core of the city to a greater and lesser extent by emphasising ethno-national elements in the urban space, there is a visible difference between them at that level. In contrast to Banja Luka, the emphasis on ethnicity based on the Islamic religion is far more intense in Sarajevo. This phenomenon is the result of a sharp increase in the number of believers after the end of the war during the 1990s, when many Islamic countries supported the spread of Islam by financing the construction of religious facilities and schools. In any case, the increase in the number of believers is visible in the Federation of Bosnia and Herzegovina and the Republic of Srpska, also as a specific reflection of the collapse of the communist

Banja Luka.

14 Although the fountain was removed from the Petar Kočić Park, it was not destroyed, and at the initiative of many citizens and associations, there is speculation about its return, however not in the park itself, but in the park near the monument to Ban Milosavljević. system. This dominant visibility also stems from the fact that Islamic believers prefer a certain style of appearance and dress, so their conspicuousness is greater. The concentration of ethno-national conspicuousness in the central city zones stems from the availability of the use of public space as a symbol of the city, which is an attractive space not only for tourists, but also for the residents of Sarajevo.

\section{STRENGTHENING THE ETHNO-NATIONAL IDENTITY OF BANJA LUKA}

The post-socialist transformation of Banja Luka caused the conversion of many existing facilities from the communist period into facilities of the institutional functioning of the Republic of Srpska. Specifically, the Army House, which was built in 1973 and until the war, was one of the most important cultural facilities with a concert hall, summer cinema, library and other facilities, and since 2000 it has been the seat of the National Assembly of the Republic of Srpska. In front of the National Assembly, next to the fountain, in 2007 the sculpture "Topola užasa" [The Poplar of Horrors] was placed, which commemorates the martyrdom of the mostly Serbian people in Jasenovac, contributing to strengthening the culture of remembrance and incorporating national identity. Also, the former mortgage bank, and later SDK (social accounting service), became the President's Palace, while the newly built facility of the Administrative Centre of the Government of the Republic of Srpska is the most impressive expression of the institutional incorporation of national values in urban space. Today, the administrative centre is a symbol of the enthronement of the statehood of the Serbian people defined by the Dayton Peace Agreement on the division of Bosnia and Herzegovina into two 
entities and the Brčko District. The construction of the centre lasted from 2002 to 2010, and was accompanied by numerous changes to the regulation plan Aleja-Centar (Malešević, 2012).

Privatisation of social ownership and transformation of the ownership structure will cause new forms and types of development in Banja Luka, among which there is an increase in capital investments in which housing and trade activities predominate. Intensive housing construction (settlements Park, Ada, Novi Borik), as well as the growth of trade activities (Emporium, Merkator, Tropik, while the industry from the previous system is almost completely devastated), creates a picture of prosperous development that does not fully correspond to the real situation. While the interest of Islamic countries in investing and business facilities mainly in trade is noticed in Sarajevo, the interest of Orthodox countries to invest in Banja Luka is not present, except from the neighbouring Serbia (shopping mall Delta Planet). On the other hand, the planned construction of the Serbian-Russian religious and cultural centre in the Aleja-Centar can be seen as a form of strengthening the common Orthodox values of the two mentioned peoples and good relations between Russia and the Republic of Srpska, while the opening of the "Jewish Cultural Centre Aria Livne" in 2014 is considered as a way of showing respect and compassion for the same destiny of the Jewish and Serbian people during World War II, as well as the friendship that arose on the basis of mutual understanding.

\section{CONCLUSION}

Both ethnic groups (Bosniaks and Serbs) had a need to rehabilitate identity urban values whose meaning was not only the aest- heticisation of urban space but also the strengthening of the national element in order to show its territorial affiliation through the experience of stratification of urban heritage. However, the difference is that in Sarajevo, the emphasis on the ethno-national world encouraged by the rehabilitation and revitalisation of urban heritage, as well as the construction of new facilities is far more noticeable, since the city was engulfed in war. This has certainly affected the need to use investments from the Islamic countries to more clearly emphasise the opposition to those who do not belong to the ethno-national majority in the urban space. A special contribution to the development of this division is made by new artifacts that were preserved after the war destruction as evidence of war conflicts. Therefore, the experience of urban space depends on the way it is offered and presented, and not only on the subjective experience of individuals. Unlike Sarajevo, Banja Luka paid more attention to the rehabilitation and reconstruction of existing urban facilities that were demolished during the Second or last war. It encouraged its ethno-national identity narrative more by converting the purpose of certain facilities, turning them into the institutional headquarters of the Republic of Srpska, than it did by the reconstruction and rehabilitation of cultural and historical heritage. The expansion of the historical centre of the city in the way of planned development of the transverse axis with contents that fit into the built structures encourages the preservation of inherited tradition and volarises the public space adapted for use by all citizens.

Both cities are facing the challenges of post-socialist transformation, recognised in the growth of foreign capital, which is mainly invested in the construction of trade facilities. Regarding the origins of interested investors, it can be concluded that countries which are 
close in religion contribute to the strengthening of ethno-national identities. Also, a comparative analysis showed that in Sarajevo the distinction between the dominant ethnicity and those who do not belong to it is much more intense, which is caused by the increase of believers who are recognised by their way of life and which is certainly contributed by a greater number of built religious facilities (mosques) after the last war. In Sarajevo, as a city that experienced war, ethno-national features are more intensively emphasised through the revitalisation of historical heritage and urban regeneration, especially artifacts that show a significant influence of the Ottoman Empire in the development of the city. In this way, religious affiliation is identified with national affiliation, which is the case with other peoples in Bosnia and Herzegovina. In Banja Luka, as a city that did not go through war, ethno-national divisions stand out far less visually, and urban reconstruction is more focused on protecting the historical heritage and possibly preserving the Culture of Remembrance from the period of suffering during World War II. A place as a concretisation of urban space that has an ideological and symbolic level mainly represents a manipulative space in the hands of dominant power structures, and its use and experience depend on the prevailing values that can therefore have an ethno-national character.

\section{REFERENCE}

Auge, M (2001). Nemjesta - uvod u moguću antropologiju supermoderniteta. Karlovac: PSEFIZMA.

Bascarsija is being built: „some“ building is being built near the old church complex. (n.d.). URL: https://www.frontal.rs/bascarsija-se-gradi-uz-kompleks-stare-crkve-ni- ce-neka-zgrada/, accessed on September 22, 2020 .

Basan, M. (2001). Za obnovu urbane sociologije - jedanaest teza. Sociologija, Vol. XLIII, No 4. URL: http://www.sociologija.org/ admin/published/2001_43/4/420.pdf

Badescu, G. (2016). (Post) colonial encounters in the post-socialist city: reshaping urban space in Sarajevo. Geografiska Annaler: Series B, Human Geography 98 (3), pp. 1-9. URL: https://onlinelibrary.wiley.com/ journal/14680467

City Hall Sarajevo (n. d.). Interduction Vijećnica. URL: https://www.vijecnica.ba/bs/home, accessed on September 22, 2020.

Čaldarović, O. (2010). Još jednom o urbanoj obnovi. Kvartal. VII, 1-2, pp.70-75. URL: https://hrcak.srce.hr/173914

Čaldarović, O. (2011). Urbano društvo na poćetku 21. Stoljeća, Zagreb: Naklada Jesenski i Turk, Hrvatsko sociološko društvo.

Development Strategy of the City of Sarajevo 2012-2020. URL: https://www.novigradsarajevo.ba/uploads/files/shares/Privreda/ Dokumenti-strateski/strategija-razvoja $\% 20$ Grada\%20Sarajevo.PDF, accessed on September 28, 2020.

Dražeta. B. (2018). Nacrt istraživanja javnih gradskih prostora u Mostaru i Sarajevu. Glasnik Etnografskog muzeja, u. No. 82 (82), str. 53-70. URL: http://www.anthroserbia.org/Content/PDF/Articles/2d1c95ce8fe740878510d90e07blaa92.pdf

Džaja, M. (1962). Banja Luka u putopisima i zapisima. Banja Luka: NP Glas. 
Gül, M., Omićević, N. (2013). Old market v. shopping malls: The Impacts of Changing Consumer practices on Sarajevo's urban morphology. Revsita Lusófona de Arquitectura Educação, Theme III, No. 8-9, pp. 673-694. URL: https://revistas.ulusofona.pt/ index.php/revlae/issue/view/635

Hirt, S. (2006). Post-socialist urban forms: notes from Sofia. Urban Geography, 27 (5), pp. 464-488. URL: https://www.tandfonline.com/ doi/abs/10.2747/0272-3638.27.5.464

Hol, S (2001). Kome treba identitet. Reč 64/10, str: 2015-233. URL: https://www.fabrikaknjiga.co.rs/rec/64/215.pdf

Hromadžić, H. (2008). Konzumerizam Potreba, životni stil, ideologija. Zagreb: Naklada Jesenski i Turk.

Husukuć, E., Zejnilović, E. (2017). The environmental aesthetics of Sarajevo: A city shaped by memory. Urbani izziv, Vol. 28, No. 1, pp. 96-106. URL: http://urbani-izziv.uirs.si/Portals/uizziv/papers/urbani-izziv-en-2017-28-01-002.pdf

Karaca, A. (2018). The Faculty of Islamic Sciences is building the Center for the Qur'an and Sunnah in Sarajevo. URL: https://www. aa.com.tr/ba/balkan/fakultet-islamskih-nauka-gradi-centar-za-kuran-i-sunnet-u-sarajevu/1217771, accessed on September 6, 2020.

Kassouha, Z. (2019). Post-conflict tourist landscapes: between the heritage of conflict and hybridisation of tourism activity. Observations from Bosnia and Herzegovina. URL: https://journals.openedition.org/ viatourism/3984\#tocfrom $1 \mathrm{n} 1$

Kuljić, T. (2006). Kultura sećenja. Beograd:
Čigija štampa.

Lefebvre, H. (1990). The Production of Space. Oxford: Blackwell Publishing.

Maksimović, D. (2015). Završena obnova Ferhadije. Retrieved from https://www.dw. com/bs/zavr\%C5\%A1ena-obnova-ferhadije/a-18529505, accessed October 5, 2020.

Malešević, M. (2012). Administrativni centar Vlade Republike Srpske. Izgradnja 66, broj 1-2, str. 57-65.

Martín-Díaz, J. (2014). Urban restructuring in post-war contexts: the case of Sarajevo. Hungarian Geographical Bulletin, 63 (3), pp. 303-317. URL: https://ojs.mtak.hu/index.php/ hungeobull/article/view/2895/2169

Mikić, Đ. (1995). Banja Luka na Krajini hvala. Banja Luka: Opština Banja Luka i Institut za istoriju.

Pajvančić Cizelj, A., Maksimov, K. (2016). Sociološki aspekti proučavanja i revitalizacije graditeljskog nasleđa. Sociologija i prostor, 54 (206) (3), str: 247-263. URL: https://hrcak.srce.hr/index. php?show=clanak\&id_clanak_jezik=252952

Perić Romić, R. (2018). Banja Luka u urbanoj transformaciji. Banja Luka: Fakultet političkih nauka Univerziteta u Banjoj Luci.

Petovar, K. (2003). Naši gradovi između države i građanina. Beograd: Institut za arhitekturu i urbanizam Srbije.

Petovar, K., Vujošević, M. (2008). Koncept javnog interesa i javnog dobra u urbanističkom i prostornom planiranju. Sociologija $i$ prostor, 46 (179) (1), str. 23-51. URL: https:// 
noj zaštiti. Banja Luka: Republički zavod za zaaštitu kulturno - istorijskog i prirodnog Radović, S. (2013). Grad kao tekst. Beograd: nasljeđa, str. 173-187. Biblioteka XX vek.

Spasić, I., Backović, V. (2017). Gradovi u Szelényi, I. (1996). Cities under socialism - and after. In: Andrusz, G., Harloe, M. potrazi za identitetom. Beograd: Filozoski fakultet, Institut za društvena istraživanja.

Stanilov, K. (2007). Taking stock of post-socialist urban development - A recapitulation: Political reform, economic development and regional growth in post-socialist Europe. In: Stanilov, K. (ed.) The Post Socialist City. Springer, pp. 1-34.

Stanković, M., Stanković, S. (2010). Integracija istorijskih repera u održiv razvoj centra Banjaluke - nova paradigma, potreba i imperativ. Zbornik pete konferencije o integrativand Szelényi, I. (eds.). Cities after socialism. Oxford, Cembridge: Blackwell Publishers.

Ševo, Lj. (1996). Urbanistički razvoj Banja Luke. Banja Luka: Opština Banja Luka, Zavod za zaštitu kulture i prirode Banja Luka.

Zlatar - Gamberožić, J., Svirčić - Gotovac, A. (2019). Urbana revitalizacija gradskih središta u Zagrebu i Ljubljani. PP. URL:

https://www.researchgate.net/publication/337153518_Urbana_revitalizacija_gradskih_sredista_u_Zagrebu_i_Ljubljani 


\section{REHABILITACIJA URBANOG NASLJEĐA U SLUŽBI ETNO-NACIONAL- NIH PODIJELA NA PRIMJERU GRADOVA SARAJEVA I BANJE LUKE}

\author{
Ključne riječi: \\ kulturno-istorijsko \\ nasljeđe; etno-nacionalni \\ identitet; rehabilitacija; \\ revitalizacija; prostor.
}

Autor:

Dr Ranka Perić-Romić je vanredni profesor Fakulteta političkih nauka Univerziteta u Banjoj Luci.

Korespodencija:

ranka.peric-romic@fpn.unibl.org

Oblast:

Posebne sociologije

DOI:

10.5937/politeia0-29337

Datum prijema članka:

10.10.2020

Datum prihvatanja

članka za objavljivanje:

03.12.2020.

\section{Rezime}

$U$ radu se razmatra uticaj procesa rehabilitacije $i$ revitalizacije kulturno-istorijskog nasljeđa gradova Banje Luke i Sarajeva na osnaživanje etno-nacionalnih politika/obrazaca podijeljenog društva. Posebna pažnja biće posvećena procesima očuvanja urbanih središta/istorijskih jezgara navedenih gradova, koji su prepoznatlivi kao prostor $i$ razdvajanja $i$ distanciranja za "nepripadajuće" etničke grupe. U tom smislu, rehabilitacija urbanog nasljeda gradova Banje Luke i Sarajeva neće biti isključivo problematizovana kao očuvanje i estetizacija kulturno-istorijske baštine „per se“, već kao vid instrumentalizacije urbanog prostora u svrhu prenaglašavanja etno-nacionalnih identiteta u postratnom periodu. Istraživanje će biti prvenstveno zasnovano na uporedno-istorijskoj analizi raspoloživih podataka o dosadašnjem razvoju urbanih središta. Rezultati istraživanja ukazuju da se navedena instrumentalizacija urbanog nasljeđa manifestuje kroz planiranje i izgradnju/obnovu specifičnih objekata koji se (ne) opravdano uklopaju u postojeći kulturno-istorijski kontekst karakterističan za te gradove. Iz te perspektive primjetno je da kulturno-istorijska jezgra gradova Banje Luke i Sarajeva danas imaju daleko značajniju ulogu u promovisanju etnonacionalnih identiteta i podjela nego što je to bio slučaj u prošlosti. Karakter tih procesa nema isključivo intencionalna obilježja, nego je uslovljen i drugim aktulenim politikama urbanog razvoja koje nemaju etno-nacionalnu pozadinu. 